\title{
Accounting
}

\section{Efficient market hypothesis and calendar effects: Empirical evidences from the Vietnam stock markets}

\author{
Pham Dan Khanha* and Pham Thanh Dat ${ }^{\mathrm{b}}$
}

${ }^{a}$ School of Advanced Education Programs, National Economics University, 207 Giai Phong Road, Hanoi, Vietnam ${ }^{b}$ School of Banking and Finance, National Economics University, 207 Giai Phong Road, Hanoi, Vietnam

\begin{tabular}{l}
\hline C H R O N I C L E \\
\hline Article history: \\
Received March 72020 \\
Received in revised format March \\
102020 \\
Accepted May 82020 \\
Available online \\
May 82020 \\
\hline Keywords: \\
Seasonal effect \\
Stock return \\
Calendar effect \\
Dummy Variable Regression \\
EMH
\end{tabular}

\section{A B S T R A C T}

\begin{abstract}
Vietnam's stock market although has small scale without a long history of development but the exchange has just started for a massive development. There have also been a number of anomalies, suggested that the market is not efficient. Therefore, there is a possibility that active investors with right strategy can consistently achieve higher profit than the market portfolio. This paper analyzes the statistical and economic significance of the calendar anomalies to propose appropriate strategies or recommendations. Studying the calendar anomalies in Vietnam also diversifies the research scope and validates some hypotheses in the past. In this research, the authors just analyze the monthly effects and the experimental results of this study may have significant implications not only for financial managers, financial advisers and investors but also for government to implement policy on stock market.
\end{abstract}

(C) 2020 by the authors; licensee Growing Science, Canada

\section{Introduction}

Calendar effect produces higher or lower yields depending on the nature of the time series (Ariel, 1990). These effects are called market abnormalize since these abnormalize cannot be explained by traditional asset pricing models. Examples of some common effects are January Effect (Haug \& Hirschey, 2006), Day-of-the-week effect, Turn of the week effect, etc. (Bouman \& Jacobsen, 2002) However, the existence of seasonal factors in stock return is contradicted by an important financial theory called Efficient Market Hypothesis (EMH) (Floros, 2008). The efficient market hypothesis plays an important role in financial model. New data is constantly being added to the market through economic reports, media companies, political reports, and possibly public surveys. If the market is effective in terms of information, stock prices will be adjusted quickly and accurately according to new information. According to EMH, stock prices fully reflect all available information on the market. Since all the information has been included in the price, a stock investor cannot make any surplus profit. Malkiel and Fama (1970) were the first who synthesized and disseminated effective forms of market. There are three variants of the hypothesis: "weak", "semi-strong", and "strong" form.

\subsection{Weak form efficiency}

This kind of market theory states that the current stock market is a reflection of all the weaknesses of the stock market (historical information), including historical prices, yields in past or changes in price or yield levels at times. In a weak market, the current

* Corresponding author.

E-mail address: khanhpd@neu.edu.vn (P.D. Khanh) 
market price reflects all past earnings and all information on the market. The market thus assumes that yields of past securities as well as other information are not linked to the future (independent yields). In other words, it is not possible to forecast future stock prices or to make profitable gains on the basis of their similar information in the past (Gultekin \& Gultekin, 1983).

\subsection{Semi-strong form efficiency}

The Semi - strong form effective market theory states that stock prices will rapidly adjust to any public information, i.e. the current price reflects all current market information (or close to present), as well as in the past.

\subsection{Strong form efficiency}

In strong-form efficiency, share prices reflect all information, public and private, and no one can earn excess returns. So in a highly efficient market, the user can have all the information possible, whether the information is publicly available or not.

\section{Theoretical background}

\subsection{Understand of Ho Chi Minh Stock Exchange Ho Chi Minh City (HOSE):}

The Ho Chi Minh City Securities Trading Center (HoSTC) located in Ho Chi Minh City, was officially inaugurated on July 20, 2000, and trading commenced on July 28, 2000. Initially, two stocks were listed, Refrigeration Electrical Engineering Joint Stock Corporation (REE) and Saigon Cable and Telecommunication Material Joint Stock Company (SACOM). On 8 August 2007, HoSTC was renamed and upgraded to the Ho Chi Minh Stock Exchange (HOSE). This is the largest stock exchange of Vietnam at the moment.

\subsection{Market Anomalies}

A market anomaly is an irregular condition that is inappropriate or deviates from an efficient market hypothesis. The anomaly here is one of the phenomena in the marketplace, where things are found that should not exist and it is assumed that efficient markets exist. Investors can take advantage of conditions in the event of market anomalies to gain abnormal returns on investments (Wong et al., 2006). Jamróz and Koronkiewicz (2014) and Lopez Bernal et al. (2013) state that an anomalous analysis is usually based on observations of long-term financial time series to study its effects and its repetition. Long-term series must be significant since they lower the likelihood of detecting related phenomena. An ongoing anomaly is a necessary condition to create a profitable investment strategy.

\subsection{Month of the Year Effect}

Schwert (2003) argued that calendar anomalies are empirical results that are inconsistent with the behavior theory of asset valuation. This claim is supported by Hawaldar et al. (2017) and Hawaldar et al. (2017). One of the anomalies that surfaced calendar month of the year is the effect that is the pattern in certain months of each year. Jahfer and Inoue (2014) suggest the most common findings regarding the study of the month of the year effect are the "January effect" and the "April effect". It is well known that stock returns in January and April are significant and different from other months of the year yield. This violates the efficient market hypothesis (EMH) partly developed by Fama in the 1960s (Fama, 1960). Sharpe et al. (1999) say there are three causes of the January effect, that is tax-loss selling, window dressing and small and beta stocks. Tax-loss selling is selling stocks with a low value with the goal of reducing tax debt, while window dressing sells stocks with low value so the year-end portfolio of a company looks good. A small or beta stock is the tendency in January for more small companies to provide a higher level of return compared to large companies.

\section{Research methods and data}

\subsection{Collecting Data}

First data is collected for a period of 15 years from March 4, 2002 through March 3, 2017 on the Ho Chi Minh City Stock Exchange (www.hsx.vn) and the first trading was 28/7/2000, however, at this time the stock market trading 3 was days per week until 4/3/2002. Based on the closing index of the VN-Index, a natural logarithmic variation was made for the main data. To create a time series of continuous profit, monthly profit was calculated according to the formula below:

$R_{t}=\ln \left(P_{t}-P_{t-1}\right) \times 100$,

where:

$\mathrm{R}_{\mathrm{t}}$ : Return of stock on day $t$

$\mathrm{P}_{\mathrm{t}}$ : The closing price (closing price) on day $t$

$\mathrm{P}_{\mathrm{t}-1}$ : The closing price (closing price) on day $t-1$ 


\subsection{Research Methodology}

The initial model for checking the monthly seasonality is as follows:

$$
R_{t}=\alpha_{1}+\alpha_{2} M 2+\alpha_{3} M 3+\alpha_{4} M 4+\alpha_{5} M 5+\alpha_{6} M 6+\alpha_{7} M 7+\alpha_{8} M 8+\alpha_{9} M 9+\alpha_{10} M 10+\alpha_{11} M 11+\alpha_{12} M 12+\varepsilon_{\mathrm{t}},
$$

where $R_{t}$ is $\log$ of market yield, M1.....M12 are dummy variables which represent January to December, respectively (for example, M2 $=1$ if data observed is February and 0 otherwise), Intercept $\alpha_{1}$ represents the mean yield in January and coefficients $\alpha_{2} \ldots \alpha_{12}$ represent the average difference in market yields between January and the other months, $\varepsilon_{\mathrm{t}}$ represents the random error derived from the classical assumption that it has a mean value of 0 assumed to be independent and distribute the same. The first model, used to test the seasonal factor effect on stock returns is the Ordinary Least Square (OLS) regression. The result of the OLS regression will become a false regression if the dependent variable is non-stationary. We will first determine whether the market performance on HOSE is stationary or not. One problem that exists in this method is that the remainder can have serial correlation. To solve this problem, Engle (1982) proposed the ARCH model. Previous researchers have used both OLS and GARCH methods to test the effect of seasonal factors on market yields. However, most recent studies of this phenomenon are mainly based on the GARCH model since it eliminates some of the limitations that OLS model. Chatfield (2016), Fryzlewicz and Subba Rao (2014) also argued that an ARCH or GARCH (Auto-Regressive Conditional Heteroskedasticity or General Autoregressive Conditional Heteroskedasticity) does not assume a constant variance (heteroskedasticity) but it can safely be used for modelling and forecasting.

\section{Result}

\subsection{The Unit Root test:}

We first check the stopping of the string and Table 1 demonstrates the results.

\section{Table 1}

Correlation chart of the VN Index

\begin{tabular}{|c|c|c|c|c|c|c|}
\hline Autocorrelation & Partial Correlation & & $\mathrm{AC}$ & $\mathrm{PAC}$ & Q-Stat & Prob \\
\hline$|* * \quad|$ & $|* * \quad|$ & 1 & 0.244 & 0.244 & 222.09 & 0.000 \\
\hline & 1 & 2 & 0.016 & -0.046 & 223.04 & 0.000 \\
\hline $1 \mid$ & 11 & 3 & 0.015 & 0.023 & 223.87 & 0.000 \\
\hline |* $\quad \mid$ & |* $\quad \mid$ & 4 & 0.081 & 0.077 & 248.51 & 0.000 \\
\hline$\left.\right|^{*}$ & | & 5 & 0.079 & 0.043 & 271.62 & 0.000 \\
\hline 1 & | & 6 & 0.032 & 0.005 & 275.44 & 0.000 \\
\hline | & | & 7 & 0.039 & 0.034 & 281.17 & 0.000 \\
\hline | & | & 8 & 0.020 & -0.003 & 282.68 & 0.000 \\
\hline 1 & | & 9 & -0.007 & -0.020 & 282.85 & 0.000 \\
\hline | & | & 10 & 0.002 & 0.004 & 282.87 & 0.000 \\
\hline | & | & 11 & 0.019 & 0.011 & 284.17 & 0.000 \\
\hline | & | & 12 & 0.031 & 0.019 & 287.70 & 0.000 \\
\hline | & | & 13 & 0.061 & 0.053 & 301.59 & 0.000 \\
\hline | & | & 14 & 0.033 & 0.007 & 305.70 & 0.000 \\
\hline | & | & 15 & -0.005 & -0.016 & 305.78 & 0.000 \\
\hline | & | & 16 & -0.006 & -0.004 & 305.92 & 0.000 \\
\hline | & I & 17 & 0.030 & 0.024 & 309.27 & 0.000 \\
\hline 1 & | & 18 & 0.039 & 0.016 & 314.89 & 0.000 \\
\hline | & | & 19 & 0.032 & 0.018 & 318.76 & 0.000 \\
\hline 1 & | & 20 & 0.028 & 0.017 & 321.72 & 0.000 \\
\hline | & | & 21 & 0.033 & 0.020 & 325.75 & 0.000 \\
\hline | & | & 22 & 0.054 & 0.041 & 336.69 & 0.000 \\
\hline | & | & 23 & 0.045 & 0.020 & 344.34 & 0.000 \\
\hline | & | & 24 & 0.033 & 0.011 & 348.48 & 0.000 \\
\hline 1 & 1 & 25 & 0.006 & -0.015 & 348.59 & 0.000 \\
\hline | & | & 26 & -0.003 & -0.014 & 348.63 & 0.000 \\
\hline 1 & | & 27 & 0.013 & 0.006 & 349.29 & 0.000 \\
\hline 1 & | & 28 & 0.023 & 0.012 & 351.29 & 0.000 \\
\hline 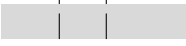 & | & 29 & -0.011 & -0.025 & 351.77 & 0.000 \\
\hline 1 & 1 & 30 & 0.010 & 0.017 & 352.14 & 0.000 \\
\hline i & 1 & 31 & 0.003 & -0.008 & 352.18 & 0.000 \\
\hline | & | & 32 & 0.024 & 0.022 & 354.35 & 0.000 \\
\hline 1 & | & 33 & 0.018 & 0.007 & 355.60 & 0.000 \\
\hline 1 & 1 & 34 & 0.014 & 0.004 & 356.29 & 0.000 \\
\hline 1 & 1 & 35 & -0.016 & -0.031 & 357.26 & 0.000 \\
\hline & 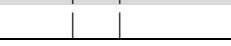 & 36 & 0.011 & 0.017 & 357.75 & 0.000 \\
\hline
\end{tabular}


Table 2 shows the test result of stopping with unit root on VN-Index. Testing the ADF is a common method for unit testing.

Table 2

Unit Root test results for the Index series

Null Hypothesis: RT has a unit root Exogenous: Constant Lag Length: 3 (Automatic - based on SIC, maxlag=21)

\begin{tabular}{|c|c|c|c|c|}
\hline \multirow{2}{*}{\multicolumn{2}{|c|}{ Augmented Dickey-Fuller test statistic }} & & \multirow{2}{*}{$\begin{array}{ll}t-S t a t i s t i c \\
-26.46183 \\
\end{array}$} & \multirow{2}{*}{$\begin{array}{c}\text { Prob.* } \\
0.0000 \\
\end{array}$} \\
\hline & & & & \\
\hline \multirow[t]{3}{*}{ Test critical values: } & $1 \%$ level & & -3.431914 & \\
\hline & $5 \%$ level & & -2.862116 & \\
\hline & $10 \%$ level & & -2.567120 & \\
\hline \multicolumn{5}{|c|}{ *MacKinnon (1996) one-sided p-values. } \\
\hline Variable & Coefficient & Std. Error & t-Statistic & Prob. \\
\hline $\mathrm{RT}(-1)$ & -0.713862 & 0.026977 & -26.46183 & 0.0000 \\
\hline $\mathrm{D}(\mathrm{RT}(-1))$ & -0.032518 & 0.024130 & -1.347582 & 0.1779 \\
\hline $\mathrm{D}(\mathrm{RT}(-2))$ & -0.080840 & 0.020337 & -3.975062 & 0.0001 \\
\hline $\mathrm{D}(\mathrm{RT}(-3))$ & -0.077208 & 0.016319 & -4.731261 & 0.0000 \\
\hline $\mathrm{C}$ & 0.026349 & 0.022776 & 1.156917 & 0.2474 \\
\hline R-squared & 0.383862 & \multicolumn{2}{|c|}{ Mean dependent var } & 0.000486 \\
\hline Adjusted R-squared & 0.383202 & \multicolumn{2}{|c|}{ S.D. dependent var } & 1.770965 \\
\hline S.E. of regression & 1.390854 & \multicolumn{2}{|c|}{ Akaike info criterion } & 3.499051 \\
\hline Sum squared resid & 7217.527 & \multicolumn{2}{|c|}{ Schwarz criterion } & 3.507383 \\
\hline Log likelihood & -6531.226 & \multicolumn{2}{|c|}{ Hannan-Quinn criter. } & 3.502014 \\
\hline F-statistic & 581.1160 & \multicolumn{2}{|c|}{ Durbin-Watson stat } & 2.006565 \\
\hline Prob(F-statistic) & 0.000000 & & & \\
\hline
\end{tabular}

We see, result in the RT sequence being the stop string. Thus, we can implement the OLS model to test the impact of seasonal factors.

\subsection{OLS Model result}

Table 3 below shows the monthly effect on the Ho Chi Minh Stock Market. According to the results of regression analysis by method (OLS), it shows that January market yield is higher than the rest of the year and the results are meaningful when the level of significance is five percent.

Table 3

Results of OLS estimation procedures for VN-Index daily returns

\begin{tabular}{|c|c|c|c|c|}
\hline \multicolumn{5}{|c|}{ Dependent Variable: RT Method: Least Squares } \\
\hline Variable & Coefficient & Std. Error & t-Statistic & Prob. \\
\hline M1 & 0.276559 & 0.085482 & 3.235282 & 0.0012 \\
\hline M2 & 0.060351 & 0.091315 & 0.660906 & 0.5087 \\
\hline M3 & 0.039349 & 0.078922 & 0.498578 & 0.6181 \\
\hline M4 & 0.144513 & 0.083584 & 1.728948 & 0.0839 \\
\hline M5 & -0.059152 & 0.081807 & -0.723063 & 0.4697 \\
\hline M6 & -0.014472 & 0.080263 & -0.180313 & 0.8569 \\
\hline M7 & -0.075163 & 0.078804 & -0.953795 & 0.3402 \\
\hline M8 & 0.098169 & 0.079042 & 1.241988 & 0.2143 \\
\hline M9 & 0.050248 & 0.082613 & 0.608233 & 0.5431 \\
\hline M10 & -0.066660 & 0.078922 & -0.844627 & 0.3984 \\
\hline M11 & -0.057589 & 0.080389 & -0.716384 & 0.4738 \\
\hline M12 & 0.070477 & 0.078922 & 0.892992 & 0.3719 \\
\hline R-squared & 0.004619 & \multicolumn{2}{|c|}{ Mean dependent var } & 0.035208 \\
\hline Adjusted R-squared & 0.001682 & \multicolumn{2}{|c|}{ S.D. dependent var } & 1.439247 \\
\hline S.E. of regression & 1.438035 & \multicolumn{2}{|c|}{ Akaike info criterion } & 3.567636 \\
\hline Sum squared resid & 7709.303 & \multicolumn{2}{|c|}{ Schwarz criterion } & 3.587616 \\
\hline Log likelihood & -6659.480 & \multirow{2}{*}{\multicolumn{2}{|c|}{ Hannan-Quinn criter. }} & 3.574743 \\
\hline Durbin-Watson stat & 1.519726 & & & \\
\hline
\end{tabular}

The above conclusion is based on OLS results. One major problem encountered with the OLS model is that this model ignores the different time variations (ARCH effects) of profit. Previous studies have found that the ARCH effect is present in market outbreaks. If the ARCH effect persists in the research data then the GARCH $(1,1)$ model will be used. To test the existence of the ARCH effect, Lagrange Multiplier (LM) testing by Engel (1982), was performed with a selected time delay of 6.

\subsection{Test LM and GARCH model}

Table 4 presents the LM test results. LM tests show that $\mathrm{ARCH}$ is present in the model. Furthermore, it is significant at $1 \%$. The $\mathrm{ARCH}-\mathrm{LM}$ test results show that the ARCH effect exists in the research data (market yield curve) 
Table 4

Results of the ARCH LM Test

Heteroskedasticity Test: ARCH

\begin{tabular}{|c|c|c|c|c|}
\hline F-statistic & 159.4150 & \multicolumn{2}{|c|}{ Prob. F(7,3725) } & 0.0000 \\
\hline Obs*R-squared & 860.5155 & \multicolumn{2}{|c|}{ Prob. Chi-Square(7) } & 0.0000 \\
\hline \multicolumn{5}{|c|}{ Test Equation: Dependent Variable: RESID ${ }^{\wedge} 2$} \\
\hline Variable & Coefficient & Std. Error & t-Statistic & Prob. \\
\hline $\mathrm{C}$ & 0.623393 & 0.074272 & 8.393406 & 0.0000 \\
\hline $\operatorname{RESID}^{\wedge} 2(-1)$ & 0.264739 & 0.016376 & 16.16611 & 0.0000 \\
\hline $\operatorname{RESID}^{\wedge} 2(-2)$ & 0.139069 & 0.016906 & 8.225979 & 0.0000 \\
\hline $\operatorname{RESID}^{\wedge} 2(-3)$ & 0.043827 & 0.017019 & 2.575189 & 0.0101 \\
\hline $\operatorname{RESID}^{\wedge} 2(-4)$ & 0.080259 & 0.016983 & 4.725758 & 0.0000 \\
\hline $\operatorname{RESID}^{\wedge} 2(-5)$ & 0.070994 & 0.017019 & 4.171431 & 0.0000 \\
\hline $\operatorname{RESID}^{\wedge} 2(-6)$ & 0.066281 & 0.016906 & 3.920514 & 0.0001 \\
\hline RESID^2(-7) & 0.032167 & 0.016377 & 1.964177 & 0.0596 \\
\hline R-squared & 0.230516 & \multicolumn{2}{|c|}{ Mean dependent var } & 2.062028 \\
\hline Adjusted R-squared & 0.229070 & \multicolumn{2}{|c|}{ S.D. dependent var } & 4.067436 \\
\hline S.E. of regression & 3.571316 & \multicolumn{2}{|c|}{ Akaike info criterion } & 5.385886 \\
\hline Sum squared resid & 47509.76 & \multicolumn{2}{|c|}{ Schwarz criterion } & 5.399227 \\
\hline Log likelihood & -10044.76 & \multicolumn{2}{|c|}{ Hannan-Quinn criter. } & 5.390632 \\
\hline F-statistic & 159.4150 & \multicolumn{2}{|c|}{ Durbin-Watson stat } & 2.002041 \\
\hline Prob(F-statistic) & 0.000000 & & & \\
\hline
\end{tabular}

\section{Table 5}

Results of the GARCH model test

Dependent Variable: RT

Method: ML - ARCH (Marquardt) - Normal distribution

\begin{tabular}{lllll}
\hline Variable & Coefficient & Std. Error & z-Statistic & Prob. \\
\hline M1 & 0.075754 & 0.048049 & 1.576599 & 0.1149 \\
M2 & 0.086394 & 0.068100 & 1.268626 & 0.2046 \\
M3 & 0.030078 & 0.048442 & 0.620909 & 0.5347 \\
M4 & 0.151049 & 0.055249 & 2.733992 & 0.0063 \\
M5 & -0.032364 & 0.053079 & -0.609731 & 0.5420 \\
M6 & 0.005753 & 0.054176 & 0.106198 & 0.9154 \\
M7 & -0.072439 & 0.043955 & -1.648010 & 0.0994 \\
M8 & -0.014043 & 0.025138 & 0.5764 \\
M9 & 0.019952 & 0.048731 & -0.558643 & 0.6822 \\
M10 & -0.033122 & 0.037977 & 0.3831 \\
M11 & -0.097962 & 0.043815 & 0.409424 & 0.0254 \\
M12 & 0.035979 & 0.055603 & -0.872153 & 0.5176 \\
\hline C & Variance Equation & & -2.235840 & 0.647073 \\
RESID(-1)^2 & 0.044078 & 0.005056 & & 0.0000 \\
GARCH(-1) & 0.248920 & 0.015393 & 16.17136 & 0.0000 \\
\hline R-squared & 0.752832 & 0.011822 & 63.68040 & 0.0000 \\
Adjusted R-squared & 0.002333 & Mean dependent var & & 0.035208 \\
S.E. of regression & -0.000611 & S.D. dependent var & & 1.439247 \\
Sum squared resid & 1.439687 & Akaike info criterion & & 3.142100 \\
Log likelihood & 7727.015 & Schwarz criterion & & 3.167074 \\
Durbin-Watson stat & -5860.727 & Hannan-Quinn criter. & & 3.150983 \\
\hline
\end{tabular}

We find that the p-value of resid $\wedge^{\wedge} 2(-7)$ is not statistically meaningful at the $10 \%$ level, so that the ARCH effect of the model is of degree 6. Since this time series has an ARCH effect, changing the model estimation using the LS - Least Squares method, in the next step the GARCH $(1,1)$ model is used. The results of the GARCH model are shown in Table 5. The results obtained from the GARCH $(1,1)$ model indicate that the stock price change rule exists on HOSE. Specifically, market yields for January were higher than the average for the rest of the year. The difference in market yields in January over the rest of the year was statistically significant at 5\%. This phenomenon can be explained by the January first month of the new year, Vietnamese investors in this period usually have some idle capital. In addition, January is in the stage that institutional investors, domestic and foreign investment funds after the review, restructuring the portfolio, adjusting the budget to invest in the market. Moreover, 
some information about the country's economic situation in the previous year as well as development orientations for the next year have been announced, making investors more remarkable in their investment strategy. That's why stock prices tend to rise. Unlike January, research results from the GARCH $(1,1)$ model indicate that the market index fell in November at a statistically significant $5 \%$. The market decline in November may be explained by the fact that November is in the period of price adjustment of the market due to the previous period prices have increased excessively. In addition, November is the time when economic indicators, economic information, and financial statements of companies are published. This, in turn, gives investors the opportunity to evaluate and restructure their portfolio, eliminating low-yielding securities that are more suited to the situation.

\section{Conclusions and recommendations}

\subsection{Conclusion}

The study has used the VN-Index series over time from March 4, 2002 to March 3, 2017 and the empirical results from the OLS and GARCH models (1.1) have shown the impact of seasonal factors on the market price on HOSE. Specifically, the results of regression analysis by OLS method indicate that the VN-Index increased in January. The GARCH (1.1) analysis has shown that in addition to the VN-Index rising in January, the index fell in November.

\subsection{Limitations and recommendations for subject development}

The study just analyzed the HOSE data so it does not reflect the overall situation of the stock market in Vietnam. Future research papers can further be expanded by using other indices on the Ho Chi Minh Stock Exchange or can be further researched on the Hanoi Stock Exchange, thereby improving the market efficiency of the market. In addition, future studies may be performed with a variety of other seasonal effects, such as the effects of day and year and the effects of holidays. As we all know that different stock markets will have different states, so seasonal effects can produce surprisingly different results in each stock market. To broaden the scope of this research, we need to not only check seasonality, but also we have to examine some of the abnormalities in the Vietnamese stock market.

\section{References}

Ariel, R. A. (1990). High stock returns before holidays: Existence and evidence on possible causes. The Journal of Finance, 45(5), 16111626.

Bouman, S., \& Jacobsen, B. (2002). The Halloween indicator," Sell in May and go away": Another puzzle. American Economic Review, 92(5), 1618-1635.

Chatfield, C. (2016). The analysis of time series: an introduction. CRC Press.

Engle, R. F. (1982). Autoregressive conditional heteroscedasticity with estimates of the variance of United Kingdom Inflation. Econometrica, 50(4), 987-1007.

Malkiel, B. G., \& Fama, E. F. (1970). Efficient capital markets: A review of theory and empirical work. The Journal of Finance, 25(2), 383417.

Fama, E. F. (1960). Efficient Markets Hypothesis (Doctoral dissertation, PhD Thesis, Ph. D. dissertation, University of Chicago Graduate School of Business).

Floros, C. (2008). The monthly and trading month effects in Greek stock market returns: 1996-2002. Managerial Finance, 34(7), 453-464.

Fryzlewicz, P., \& Subba Rao, S. (2014). Multiple-change-point detection for auto-regressive conditional heteroscedastic processes. Journal of the Royal Statistical Society: series B (statistical methodology), 76(5), 903-924.

Gultekin, M. N., \& Gultekin, N. B. (1983). Stock market seasonality: International evidence. Journal of Financial economics, 12(4), 469-481.

Hawaldar, I. T., Bolar, S., \& Pinto, P. (2017). Empirical Testing of Month of the Year Effect on Selected Commercial Banks and Services Sector Companies Listed on Bahrain Bourse. International Journal of Economics and Financial Issues, 7(2), 426-436.

Jahfer, A., \& Inoue, T. (2014). Financial development, foreign direct investment and economic growth in Sri Lanka. International Journal of Economic Policy in Emerging Economies, 7(1), 77-93.

Jamróz, P., \& Koronkiewicz, G. (2014). The occurrence of the day-of-the-week effects on Polish and major world stock markets. Studies in Logic, Grammar and Rhetoric, 37(1), 71-88.

Lopez Bernal, J. A., Gasparrini, A., Artundo, C. M., \& McKee, M. (2013). The effect of the late 2000s financial crisis on suicides in Spain: an interrupted time-series analysis. The European Journal of Public Health, 23(5), 732-736.

Haug, M., \& Hirschey, M. (2006). The January effect. Financial Analysts Journal, 62(5), 78-88.

Schwert, G. W. (2003). Anomalies and market efficiency. Handbook of the Economics of Finance, 1, 939-974.

Sharpe, W. F. (1999). G., J. Alexander, e V. Bailey, Investments.

Wong, W. K., Agarwal, A., \& Wong, N. T. (2006). The disappearing calendar anomalies in the Singapore stock market. The Lahore Journal of Economics, 11(2), 123-139.

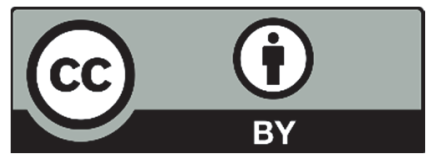

(C) 2020 by the authors; licensee Growing Science, Canada. This is an open access article distributed under the terms and conditions of the Creative Commons Attribution (CC-BY) license (http://creativecommons.org/licenses/by/4.0/). 